\section{The Rev, F. C. R. Jourdain}

The death of the Rev. F. C. R. Jourdain at his home in Southbourne, Bournemouth, on February 27 at the age of seventy-four is a grievous loss to European ornithology. Jourdain was generally recognized as the leading authority on the breeding biology of the birds of the Palæarctic region, and the accuracy and comprehensiveness of his knowledge of the subject has not been equalled by any ornithologist past or present. His great collection of the eggs of Palæarctic birds was formed in a truly scientific spirit unfortunately too rare among collectors of eggs, and its value for comparative purposes is unrivalled, so that it is greatly to be hoped that it may be preserved intact. But although Jourdain was an enthusiastic collector, he was intensely interested in every aspect of the breeding biology of birds, and his mastery of his subject was based on a happy combination of wide field experience and an encyclopædic knowledge of the literature. For many years he had made a collecting expedition almost annually, visiting in this way almost all of the more ornithologically interesting parts of Europe (excluding Russia) and North Africa, and these trips resulted in a number of valuable faunistic papers in the Ibis and elsewhere.

Jourdain tabulated and classified with amazing industry the whole mass of data on the breeding of Palæarctic birds from the extensive literature, supplemented by his own experience and that of a wide circle of correspondents, and his sections on breeding habits in the "Handbook of British Birds", now appearing, are marvels of concise and exact information which could have been written by no other ornithologist. Moreover, the enormous increase in detailed knowledge of the subject recorded in the "Handbook" as compared with its smaller predecessor, the "Practical Handbook of British Birds" (1919-23) is in very large measure directly due to the stimulus given to further investigation by his orderly systematization of the facts then known in the older work. He was also responsible for the sections on food, distribution abroad, and (jointly with me) on display. It is sad that he did not live to see the completion of this crowning achievement of his life's work in ornitho$\operatorname{logy}$; but it is gratifying to know that his sections in the final volume will be completed mainly from his own comprehensive notes. References to the various other standard works on British ornithology in which he collaborated and to his many notes and papers on British birds will be found in the longer notices in British Birds or the Ibis.

Jourdain was an unsparing critic of inaccuracy in matters of fact with regard to birds, or support of theories which he believed to be contrary to the evidence, and his frequently witty, but withering style in controversy made him enemies in some quarters. This fighting trait was very characteristic, but the reputation which it gained him gave many a quite wrong impression of his real character. This was much more truly displayed in his unfailing willingness to assist and advise every serious student of birds who asked for his help, and above all in his constant and generous encouragement of the younger generation of ornithologists, which found full scope in the years following the War of 1914-18, when he was rector of Appleton, near Oxford. The prominent part played by Oxford in recent years in the organized study of the bionomics of birds, now centred in the Edward Grey Institute of Field Ornithology, may be traced directly to his influence, and this is not the least of his contributions to the scientific study of birds to which he devoted his life.

\section{B. W. TUCKER.}

\section{Mr. E. E. M. Joyce}

ERnest E. Mills Joyce, who died on May 2 at the age of sixty-five, was one of the remarkable group of naval ratings chosen by Captain Scott for the National Antarctic Expedition of 1901, and his name will live with those of Frank Wild and Edgar Evans among the sailor explorers of his time.

On the Discovery expedition Joyce developed qualities of independence and self-reliance which led Sir Ernest Shackleton to persuade him to leave the Navy, where he was a chief petty officer, and to join the Nimrod expedition of 1907. To him Shackleton confided the responsible task of laying out the depot at the Bluff in a fixed position, with provisions for the last lap of the homeward journey. This was done after Shackleton's departure on his great southern journey, and the success of thereturnjourney was due to the perfect performance of this duty. During the winter of waiting at the base Joyce became skilled as a printer and he produced "Aurora Australis", the only book ever printed and bound in the Antarctic regions. This book is now one of the rarest finds for any collector.

Joyce was employed by Sir Douglas Mawson when equipping the Aurora expedition in 1912 to select Greenland dogs in Denmark and convey them to Tasmania. He remained in Australia until 1914, when Shackleton called on him to undertake the transport arrangements of the Ross Sea branch of that Imperial Trans-Antaretic Expedition which he had planned in a too optimistic spirit. The Aurora, under the command of Captain Aeneas Mackintosh, took the party to Macmurdo Sound, in order to lay out a line of depots as far as the Beardmore Glacier with supplies for. Shackleton and his party, who were expected to cross the Antarctic plateau from the Weddell Sea by way of the South Pole. The captain, who was in charge, and other members of the sledge party were overcome by scurvy on the way to the Beardmore Glacier, and Joyce assumed command. The sick men had to be carried on the sledges during the return and one died; but Joyce, under tremendous difficulties, laid out the depots exactly as planned, and if Shackleton had been able to land in the Weddell Sea he would have found his last stage easy. Joyce's enormous strength and ruthless determination enabled him to achieve this feat and to bring all but one of his party safely to the advanced base. He has given a grim but vivid description of this terrible journey in his "South Polar Trial", published in 1929 .
Hugh Robert MILL. 